\title{
Research on the Construction of Personnel Management Informatization in Colleges
}

\author{
Zheng Jin \\ Chongqing College of Electronic Engineering, Chongqing, China \\ 460470325@qq.com
}

Keywords: Personnel Management, Information Construction, Standardization

\begin{abstract}
With the advancement of information technology and the development of modern information computer technology, information technology has become the most development potential of the current emerging productive forces. This paper analyzes the significance, current situation and existing problems of the current information management of personnel management in colleges and universities. On this basis, use as little as possible resource consumption in exchange for as much as possible from the practical needs of teachers and students and the actual management requirements of colleges and universities management efficiency, so as to adopt scientific management, technology introduction and standardization to establish a series of methods to achieve the university personnel management information based on the strengthening of university management efficiency and quality objectives. The use of computer network technology, with modern information processing technology and tools to achieve office automation to improve the quality and efficiency of work, in order to achieve management modernization and scientific decision-making, information society has become the inevitable trend of development of administrative work.
\end{abstract}

\section{Theoretical Introduction of Personnel Management Informatization}

Personnel management is a complex system engineering, random, timeliness, frequent work, heavy workload and cumbersome. Colleges and universities as a place of higher education, colleges and universities to improve the level of information technology is a strong guarantee of quality. Personnel file is an important carrier of talent information. Under the environment of implementing the strategy of strengthening the country through talents, how to strengthen the information construction of personnel files in colleges and universities is the key to study the scientific management of archives work in colleges and universities.

The work of personnel management in colleges and universities is the basic work of personnel management in colleges and universities, and it is also an important means to promote the scientific management of personnel and improve the management level. In the whole personnel management of colleges and universities, from the forecasting and decision to the plan, organize. It is the prerequisite and basis for scientific decision-making, which is consistent with the role of information, whether it is accurate, whether the decision is correct, the survival and development of the university, and the comprehensive, accurate and timely information. High quality personnel management information is an indispensable condition for the smooth implementation of university management ${ }^{[1]}$.

The characteristics of personnel management in colleges and universities are mainly embodied in two aspects: First, the uniqueness of management object, the management object of university personnel management is the connection between teachers and teachers in the university, and the environment, organization, thing and thing. Second, the university personnel management itself has an objective development law, university personnel management theory, ideas, means and methods will be with the development of society and the times. 


\section{Current Situation and Problems of Personnel Management Informatization}

At present, the status quo of personnel management informationization in colleges and universities in our country is that there is not an integrated information management organization within the university, and the degree of integration and integration of various functional departments is not high; the information management is poorly standardized; the management of colleges and universities is important to the personnel management information Lack of knowledge; computer information management system software development is relatively backward, information management personnel to deal with information capacity is insufficient, resulting in data confusion, timeliness, data redundancy, resource duplication and other issues ${ }^{[2]}$. Fig.1 shows current situation and problems of personnel management informatization.

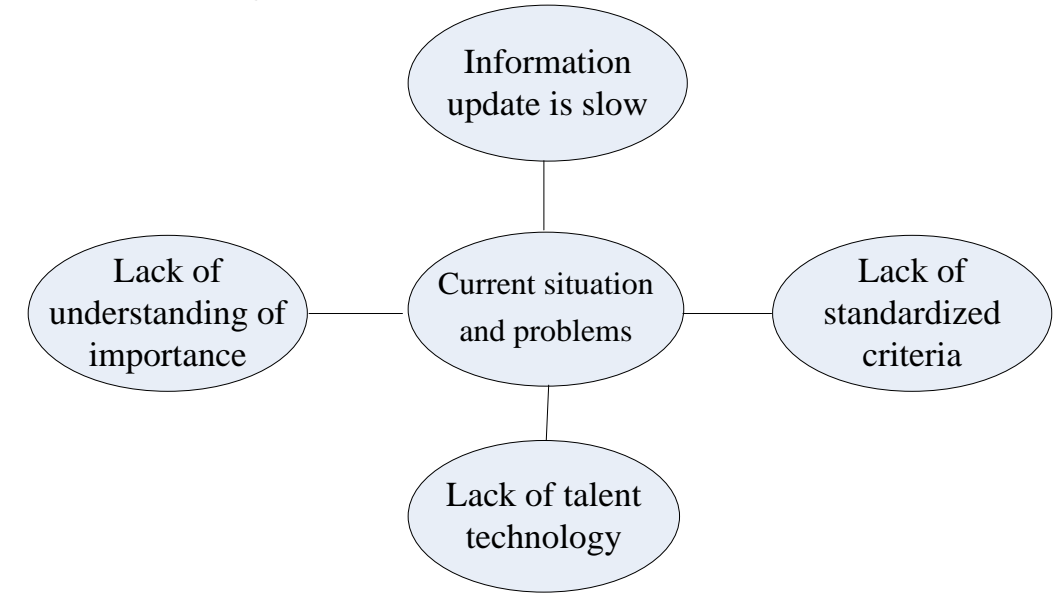

Fig. 1.Current situation and problems of personnel management informatization

Some colleges and universities managers of personnel management information construction is also lack of understanding and profound understanding of the fundamental reason is not combined with the actual situation and needs of the school, often with a certain blindness. In fact, understanding the management of information systems involved in the collection of information, management, integration, analysis and a series of operations, the need to train specialized personnel to really play the role of the system. Lack of technology for the most prominent performance of the basic information for the establishment of multiple personnel in the university personnel management departments have their own database, which resulted in human and equipment resources waste.

Therefore, it is necessary to speed up the personnel training of personnel management information and improve the information operation ability of the personnel personal and enhance the awareness of informationization, thus changing the traditional way of information construction, management and information exchange. As a part of the national informationization, it is necessary to speed up the construction of the national informationization standard system and to regulate the application and innovation in the form of laws and regulations at the same time in order to achieve healthy and steady development. Only to achieve standardization and standardization of the constraints in order to solve the management responsibilities between departments is unclear, the division of labor and other constraints of management decision-making timeliness and accuracy of the problem, so that personnel management information development norms, science ${ }^{[3]}$.

\section{Basic Contents of Personnel Management Information Construction}

The purpose of personnel management information construction is to improve the efficiency and quality of personnel management, to ensure the timely updating and security of personnel data, to achieve the sharing of personnel information, to facilitate the staff of the personnel management information query, as well as for the school's scientific decision-making important reference. Therefore, the personnel management information system should focus on solving these problems, 
and to achieve the dynamic maintenance of information ${ }^{[5]}$.

On the construction of university personnel management information, first of all need to be based on the provisions of the national information standards, followed by the Ministry of Education on the specific requirements of the construction of information technology, and ultimately according to the actual situation of each school to determine. School-level personnel management module is the university-level departments and the Institute of personnel and specialized work sector, and for basic personnel management. User management module for the majority of workers and users, the use of account information log information, according to different users to achieve the different functions to set a different operating range and permissions.

According to the actual business division of labor management, in order to achieve clear and standardized, standardized, simple user data management. The teacher management module is provided to the teachers and the scientific research department. It is mainly used for all kinds of personnel training, talent introduction, fund support information, discipline construction information and scientific research information management. Before entering the system, to confirm the identity, only the user name and user password are consistent with the user before entering the system. In order to prevent illegal users to view and modify the data, the system will be divided into three levels of users: super, edit and read-only users, that is, one, two, three users. First-level users not only have the data query, modify permissions, but also on the user's permission to use, control, you can set the user name, password and permissions

\section{Development Strategies and Recommendations}

Strengthen the information technology personnel and rules and regulations, closely unite the various departments of the city's information construction efforts, and earnestly fulfill the information service to the overall development strategy of the school responsibilities. Therefore, combined with the trend of information technology development, in view of the above problems and the status quo analysis, the development of university personnel management information strategy recommendations are as follows. Fig. 2 shows development strategies and recommendations.

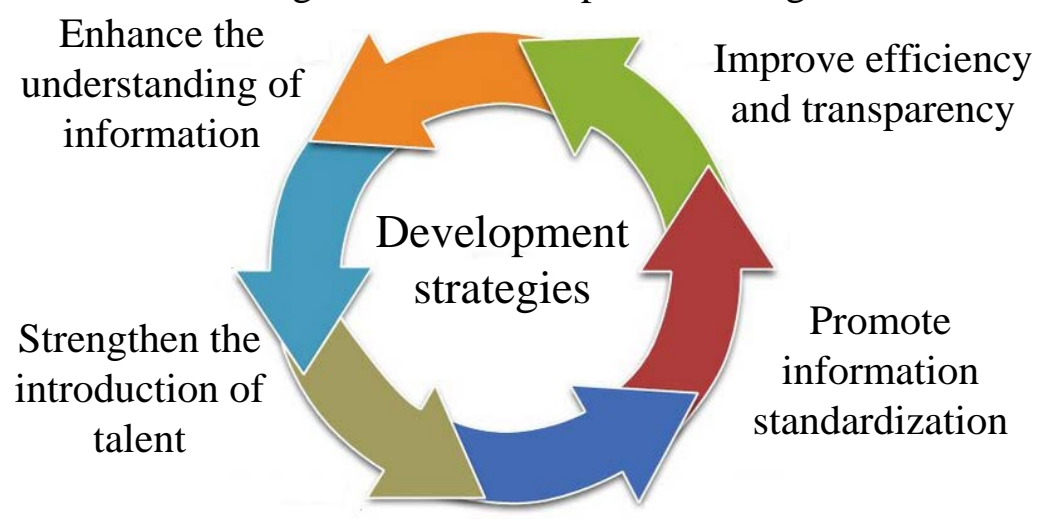

Fig. 2.The development strategies and recommendations

University personnel management information is not only a tool for personnel information management, but also regulate the means and methods of personnel management work, improve the utilization of human resources and the overall efficiency of the work, to ensure the accuracy of information and work of environmental protection. Strengthen the financial support, and strive to promote the personnel management of information technology and the introduction of talent to protect the personnel and efficient personnel, accurate management and operation as the basis for the construction, development, teaching and scientific research to provide scientific protection. In today's university personnel management must keep up with the pace of the information age, which requires the actual needs of the school personnel management work, the network information technology and personnel management of the organic combination of the establishment of a highly efficient, practical and reliable personnel management information system, Based on the system to do a timely update and maintenance of data, and strive to continue to enrich the information database. 
Personnel work must be standardized and standardized, so as to provide a strong guarantee for the construction of personnel management information in colleges and universities. Personnel management information construction should meet the specific needs of the masses and management of the actual requirements on the basis of information construction institutionalized and standardized. Each function module of personnel management is responsible for the timely maintenance of information generated in its own work. In the development of the new era of colleges and universities, we must insist on seeking truth from facts, starting from the actual needs of teachers and students and the actual requirements of university management, so that the results of information technology can truly serve the teachers and students, specifically to the university personnel information construction is to improve the school personnel Management of information construction level, improve efficiency and enhance transparency.

\section{Conclusions}

The information management of personnel management in colleges and universities is not only the information processing tool of personnel management, but also the means and methods of standardizing the personnel management. It is not only the human resource management system and the overall work efficiency to be further improved. But ensure the safety of personnel information and accurate wins, to eliminate the interference of human factors, which effectively improve the utilization of personnel information, reduce the intensity of work, and further simplify and standardize the course Construction. University personnel information platform provide full, accurate and timely information for scientific decision-making and understanding of personnel dynamics to provide an important basis. Colleges and universities with the help of modern information technology to effectively implement the personnel management information, personnel management bring a qualitative leap.

\section{Reference}

[1] Jin Bo. Network Technology and Archives Information Resource Management [J]. Archives Communication, 2007 (3): 1- 5.

[2] Van Urambcorg B, Teicher J,O'Rourke A. Managing electronic communications: a new challenge for human resource managers. The international Journal of Human Resource Management, 2012(1):19.

[3] Cui xian. Journal of Xi'an Post and Telecommunication College, 2012,17 (5): 111-116. [J]. Journal of Xi'an Post and Telecommunications University, 2012, 17 (5): 111-116.

[4] Qu yue. Application of Data Mining Technology in Human Resource Management in Colleges [J]. Computer Knowledge and Technology, 2014, (10).

[5] GU Yan sheng, WANG Gui xia, ZHAO Ming qi. Study on the Current Situation and Countermeasures of Human Resource Management in Colleges and Universities [J]. Businessist, 2015, (10). 